\title{
International Legal Regulation of the Missile Technology Control Regime in the Aspect of Private Space Company Activities
}

\author{
Valentyn Halunko \\ Doctor of Law, Professor, Editor-in-Chief of Academic Journal “Advanced Space Law”, \\ President of Company "Science and Space" (Kyiv, Ukraine) \\ E-mail: scinspace@gmail.com \\ https://orcid.org/0000-0003-1619-5028

\section{Yurii Buhlak} \\ Ph.D. in Law, a Doctoral Student, Donetsk Law Institute of the Ministry of Internal \\ Affairs of Ukraine (Kryvyi Rih, Ukraine) \\ E-mail: buglack@gmail.com \\ https://orcid.org/0000-0002-0428-0121
}

\section{Oleg Pauk}

Ph.D. student, Institute of Technical Mechanics of the National Academy of Sciences of Ukraine (Dnipro, Ukraine)

E-mail: paykoleg@gmail.com

Halunko, Valentyn, Yurii Buhlak, and Oleg Pauk (2020) International Legal Regulation of the Missile Technology Control Regime in the Aspect of Private Space Company Activities. Advanced Space Law, Volume 5, 34-47. https://doi.org/10.29202/as1/2020/5/4

In the article, the analysis of the provisions of the Missile Technology Control Regime enables to conclude that it requires to be amended, or, which is better, replaced by a new high-level international legal treaty. The authors reveal that classic civilian launch vehicles built by private space companies have a common good for humanity; in particular, they increase the chance of human survival as a result of global natural or human-made disasters. The authors conclude that a new paradigm should be implemented: from restraining the transfer of rocket technology to encouraging this process by space

\footnotetext{
(C) Halunko, Valentyn, 2020

(C) Buhlak, Yurii, 2020

(C) Pauk, Oleg, 2020
} 
International Legal Regulation of the Missile Technology Control Regime in the Aspect of Private Space Company Activities by Valentyn Halunko, Yurii Buhlak and Oleg Pauk

companies under the banner of democracies governed by the rule of law. At the same time, the authors argue that more effective international legal sanctions and controls should be implemented by the international community to prevent ballistic missiles from getting to terrorists.

Keywords: export control, weapons of mass destruction, space companies, international law, missile technology, launch vehicle, control regime, sanctions, terrorism

Received: February 10, 2020; accepted: March 2, 2020

\section{Introduction}

We, Homo sapiens, are a very young creature of nature (God) on planet Earth. Homo sapiens walk on the surface of his cradle, according to scientists, just under 200 thousand years, which is a tiny moment for the Cosmos. Obviously, the very first ones, watching the stars, already dreamed of achieving them. In the late nineteenth and early twentieth centuries, these fantasy dreams began to materialize into specific humanistic and technical knowledge. Konstantin Tsiolkovsky in his works sought to demonstrate the interdependence of a man and outer space, their continuity. He emphasized that a man as a being intelligent and creative, is a force in the universe enabled by mental and moral power to transform the nature on a growing scale and thereby actively influence the dynamics of cosmic evolution. He argued that man's fate depends upon the future of the Cosmos; the outcome of the universe depends on man's fate. Going into space for a scientist meant not only a purely practical exploration of outer space to gain power and wealth, but mostly to attain the immortality and eternity of human existence (Kasatkina, 2011).

After the start of the space epoch (October 4, 1957), humanity was given a chance to move beyond its cradle. To date, some positive results in space exploration and use have been achieved. For example, all information space is provided by telecommunications satellites in Earth's orbit.

It should be noted that from the launch of the first satellite into the Earth's orbit and to this day, all launches to outer space were made exclusively by ballistic missiles. The means of bringing cargoes and humans beyond the Earth's atmosphere with the help of a space elevator, an ion rocket engine, an antimatter engine, and a space sail remain at the level of fantasy or primary conceptual development. Today and in the nearest future, launch vehicles with liquid and robust propellant engines will remain the primary means of exploration and use of outer space.

In other words, launch vehicles and technologies for their development are a boon to humanity. They are the only way of bringing cargoes and people into the near and far space to date.

This is essential not only for providing humans and their communities on Earth with a variety of quality services and rare materials. Besides, this area affects the very fact of the survival of humanity, as the supreme matter of the Cosmos. After all, scientists warn that frequently on Earth species extinct totally. At least five examples of such extinction have been traced by biologists. Some of them argue that the sixth mass extinction of species has just begun (On Earth, 2012). At the same time, humanity as a species is also at risk of being destroyed by various natural or human-made disasters. For example, recently, we have all been concerned with the problem of the COVID-19, which is deadly, affecting less than one percent 
of humanity. This is not a direct threat of human extinction. However, the evil fate of nature, or the actions of terrorists, or the fall of a large asteroid on Earth may cause irreparable results. To prevent this, sovereign states, alone or in cooperation, should create colonies of settlements on other planets, gigantic space stations, and artificial space islands beyond Earth. It is not possible to create anything like this without classic launch vehicles.

Therefore, the probability of increasing the chance of human survival in the face of natural, man-made disasters or terrorist acts depends on the development of rocket technology, the mass construction of new launch vehicles, the involvement of new states in this process, the private investments of individuals and legal entities of different countries.

Our conclusion is supported by statements on this issue by the great thinker, scientist theorist Stephen William Hawking. In his writings, he argues that it will be difficult enough to avoid catastrophes on planet Earth in the next hundred years, not to mention the next thousand or million if the human race resides on one planet. According to him, it is time to explore other solar systems. The spread of humanity beyond planet Earth may be the only thing that will save us (Wall, 2018).

At the same time, under current conditions, a significant factor in deterring the mass development and construction of civilian launch vehicles, which is now the only way for a person to enter outer space, is the Missile Technology Control Regime (MTCR). Historically, its occurrence was objective and positive in preventing ballistic missiles from falling into the hands of terrorist and unmatured State regimes. It should be considered that the first ballistic missiles were developed for military purposes, as a means of delivery of conventional bombs, first, and then, weapons of mass destruction. However, in a modern context, it no longer ensures the security of mankind from States that successfully develop their nuclear and missile programs and threatens them with democracies governed by the rule of law. An excellent example of this is North Korea's missile and nuclear program.

Therefore, the principles and other provisions of the MTCR require further development, at least, and it would be appropriate to launch a broad debate on the subject internationally and to adopt a new paradigm for non-proliferation of ballistic missiles at the U.N. level in the context of space commercialization.

In the article, the theoretical provisions and practical implementation of MTCR will be analyzed. This problem is central, since the survival of mankind in the face of natural disasters, the emergence of new dangerous viruses and man-made disasters depends directly on the quality and quantity of civilian launch vehicles available to mankind. There are some publications in law books and other literature. However, they transfer a crucial idea that the development and construction of new ballistic missiles and technologies should be deterred. In the current context, this is an ineffective means of achieving international public interest. Totalitarian States receive such technologies, while democracies governed by the rule of law, which strictly adhere to the guidelines of international law, cannot carry out exploration and use of outer space. Moreover, democracies governed by the rule of law that possess ballistic missile technology and means of ballistic missile production cannot engage foreign partners in mutually beneficial cooperation.

Therefore, the current MTCR should be relieved for the transfer of civilian ballistic missiles and their components to democracies governed by the rule of law and private business companies that are under the banner of such States. At the same time, sanctions should be not just increased, but strict collective sanctions should be applied to States that violate international law in general, and provisions of the MTCR, in particular (A/RES/68/262, 2014). 
Moreover, the "informal" international agreement under the analysis should be replaced by an International Convention on Preventing the Transfer of Ballistic Missiles and Technology to Terrorist Subjects by the U.N. auspices. Therefore, further restraints on the proliferation of launch vehicles and their components and prevention of private space companies, entities to democracies governed by the rule of law, from producing them will cause overall damage to the international community, and we will prove it in the article.

The article is based on the following content. First, the State of affairs in the MTCR legal regulation is revealed as well as contradictions in this area is under focus, taking into account the activities of private space companies. Next, the specificities of MTCR compliance is analysed. The study proves that, although according to its principles, the MTCR does not intend to impede the peaceful use of advanced missile technology, in practice, due to the guidelines of this regime, democratic States that carefully follow export control guidelines are forced to hinder the development of their missile technologies and do not prevent totalitarian States from increasing their arsenal of ballistic missiles. In this respect, the level of international security against the spreading of ballistic missiles beyond the MTCR is under focus. The MTCR accession procedure for the new Member States is studied, and the significant bureaucratic nature of this procedure is concluded. The legal nature of sanctions for MTCR violations has been disclosed. The most substantial shortcomings and areas for improving the MTCR have been identified, given the need for active development of private space companies.

\section{Current regulation status of the missile technology control regime}

The Missile Technology Control Regime is an informal political multilateral agreement among 35 Member States in order to limit the proliferation of missiles and missile technology. Although such an agreement is not a treaty, since Member States do not have any legal obligations, but it is an essential document. MTCR's activities are consistent with U.N. efforts regarding non-proliferation and control of the export of missiles and missile technology (Frequently, 2020).

The principal objective of the MTCR, according to the statement following the results of the 32nd Plenary (October 7-11, 2019) of this general assembly, is to create mechanisms to prevent the proliferation of mass destruction delivery means [9 MTCR, 2019]. This emphasis is significant when considering the relationship between the MTCR and the real issues of exporting launch vehicles and individual items of missile technology.

The regime under analysis is based on the general export policy, which also applies to the list of items specified in the annex to the MTCR's hardware, software, and technologies. This list of questions, controlled by the international community, establishes a special regime for both military equipment and dual-use equipment. Practically all key hardware, materials, software, and technologies required for the development, production, and operation of systems capable of delivering nuclear weapons fall under this regime (WMD) (Nuclear, 2020).

The MTCR Appendix identifies two categories of equipment. The most significant concern of the world community is the restriction on the export of first category items, such as missile systems, primarily ballistic intercontinental missiles, space rockets, unmanned aerial vehicles, including cruise missiles and reconnaissance drones with a flight range of more than $300 \mathrm{~km}$ and payload of more than $500 \mathrm{~kg}$. Furthermore, this category includes payloads that launch vehicles and other aforementioned vehicles, production facilities for their production, as well as integral delivery subsystems: rocket stages and rocket engines, guidance systems, 
and warhead mechanisms into ballistic orbits. The second category includes the various and numerous missile systems according to the catalog, as well as specialized materials, fuels, technologies, and individual subsystems (Missile, 2017).

The Missile Technology Control Regime was established in 1987 by seven States (Canada, France, Germany, Italy, Japan, United Kingdom, and the United States) as an informal regime through bilateral exchange of diplomatic notes between partners. The purpose of this regime was to limit the proliferation of ballistic missiles capable of carrying nuclear warheads and unmanned weapons delivery systems of mass destruction. This regime was an additional measure to the mechanisms provided for in the Declaration on the Non-Proliferation of Nuclear Weapons. At a meeting in 1992, participants agreed to extend the scope of the MTCR to missiles and drones capable of carrying chemical and biological weapons. At present, 35 States are members of the regime. The MTCR uses a mutually agreed list of dual-use materials, equipment and technologies that can be used to construct missiles. With respect to complete rocket systems and production facilities (first category of the list), the principle of "failure as a rule" is established. Transfers of individual systems of such missiles and equipment for their production can be made only after appropriate consultations of partners. To ensure the regime's activities, its members hold regular discussions (Chechelyuk, 2013).

As of April 1 2020, 35 countries are participants in the International Missile Technology Control Regime, namely: Argentina, Australia, Austria, Belgium, Bulgaria, Brazil, Canada, Czech Republic, Denmark, Finland, France, Germany, Greece, Hungary, Iceland, India, Ireland, Italy, Japan, Luxembourg, Netherlands, New Zealand, Norway, Poland, Portugal, Republic of Korea, Russian Federation, South Africa, Spain, Sweden, Switzerland, Turkey, Ukraine, United Kingdom, United States (MTCR, 2020).

The MTCR Guidelines provide for that exporting countries must be obliged to assess the risks for the transfer of missile technology, such as prevention of proliferation and delivery of weapons of mass destruction, as a result of the transfer; the mission (purpose) and objectives of the recipient's rocket and space programs; assessment of the probable use of the transferred items for the delivery of weapons of mass destruction and recipient States' representations of international legal refusal of such actions; application of corresponding multilateral agreements; consideration of the risk of controlled items falling into the hands of terrorist groups and individuals (Guidelines, 2002).

However, it should be considered that space exploration is now entering a new era of innovation and change. Nowadays, new technologies, new uses of space, and decreasing costs have made space flight much more accessible. Private space companies launch satellites, resupply the International Space Station, and even offer space flights to citizens. Currently, there are space agencies in 72 countries, including China, Japan, and India. The three largest space agencies are NASA in the US, Roscosmos in Russia, and the ESA in Europe (Hofford, 2019). In other words, States that aspire to explore and use outer space are twice as likely as MTCR participants.

At the same time, private space companies play an increasing role in the space agencies of nation States. Three American ones are the most powerful. SpaceX is the most famous private space company. It was founded in 2002 by Elon Musk, an entrepreneur, for the strategic purpose of colonizing Mars. It is the first commercial company to deliver cargo that has secured a contract with NASA for the transportation of astronauts to the ISS. Its Falcon 9 and Falcon Heavy rockets, for the first time, have launched reusable rockets. The founder of private space company Blue Origin (2000) is the legendary Amazon founder Jeff Bezos. This company aims 
to provide access to space for private individuals. It has developed a reusable rocket New Shepard. This launch vehicle has undergone multiple successful flights. Blue Origin focuses on civilian space and the provision of 'low cost' space travel services. The company has also signed a number of contracts to use their rocket to launch civilian commercial satellites. In addition, Blue Origin has created the BE-4 rocket engine. They plan to sell it to other rocket companies that plan to construct launch vehicles. Richard Branson's Virgin Galactic was founded in 2004. It is an extension of the Virgin brand into the space tourism industry. In 2018, Virgin Galactic successfully launched a reusable space shuttle SpaceShipTwo that carried a passenger. This is great news for the 680 customers who have already paid the $\$ 200,000$ deposit for the space travel. In general, Virgin Galactic aims to dominate the commercial space travel market by reusable space shuttles (Hofford, 2019).

From the perspective of law, all U.S. private space companies operate in the legal field of U.S. national law as well as international law ratified by Congress. Their activities are under the control of NASA, as a national body controlling the activities of private space companies on behalf of the U.S. government. This includes strict adherence to MTCR guidelines. In other MTCR space member States, private space companies comply with the same legal mechanism. However, it should be considered that not only the companies and their officials, but also the national space agency of the country and the government of the State as a whole are responsible for the violation of the MTCR by private space companies.

\section{Specificities of compliance with the missile technology control regime by U.S. private space companies}

As a general rule, the MTCR does not intend to interfere with the peaceful use of advanced missile technology, national space programs, or international space cooperation until such programs can potentially facilitate the delivery of nuclear or other weapons of mass destruction (Ozga, 1994). Modern ballistic missiles are a system of cargo delivery to Earth orbit or distant space, not weapons delivery (Novikov, 2012). Nowadays, most states that have entered into this regime as a result of bilateral agreements with the U.S. government have tighter restrictions than those set out in the MTCR since chemical and biological warheads can be deployed on small rocket systems with a flight range of less than $300 \mathrm{~km}$ and a payload of less than $500 \mathrm{~kg}$ (Ozga, 1994).

According to most experts, the MTCR crisis is largely caused by the initial following the principle of non-proliferation of missile technologies, which is similar to the non-proliferation regime of nuclear weapons. This meant its versatility and legally binding procedures. However, under the current conditions, the legal control mechanism is implemented within the framework of export control legal instruments regulated by national legislation. Accordingly, MTCR states impose legal restrictions, while other non-member States formally remain free to act (Novikov, 2012).

However, the commercialization of space activities and the active involvement of private space companies in the process has had positive results; for example, $\$ 5.8$ billion was invested in 2019. Private funds make record-breaking investments in the space industry. Typically, private space companies are funded from three sources: corporate capital, venture capital, and individual or angel capital. Experts have proven that a $\$ 140$ million investment is key taking a company from start-up to its first launch. Moreover, it should be noted that most of the space companies have a little more than a ten-year history. Nevertheless, they have received nearly 
\$26 billion in investments since 2009 (Sheetz, 2020).

Successful private American space companies are: Bigelow Aerospace, its objectives include providing a low-cost, low earth orbit (LEO) human-rated space station (founder: Robert Bigelow (1998); Copenhagen Suborbitals, its objective is to launch space tourists into suborbital space. Has performed 45 engine tests to date (founders: Kristian von Bengtson, Peter Madsen (2008)); Deep Space Industries, space company planning to mine asteroids for usable materials (founders: Rick Tumlinson, David Gump (2013)); Frontier Astronautics, it provides hard-to-get technology and services to the space industry, in particular, rocket engines and attitude control systems; Intelsat, leading provider of satellite services worldwide; Masten Space, a company that designs, builds, tests, and operates reusable launch vehicles (founder: David Masten (2004)); Moon Express (MoonEx), a company with the goal of mining the Moon for natural resources (founders: Robert D. Richards, Naveen Jain, Barney Pell (2010)); Planetary Resources, Asteroid mining company, with the goal to establish a new paradigm for solar system resource discovery and utilization (founders: Eric Anderson, Peter Diamandis); Rocketplane, a creator of a suborbital spacecraft for suborbital flights space tourists; Ventions, currently focused on development of small-scale propulsion systems (2004); XCOR Aerospace, focused on the design, development, and production of reusable launch vehicles (founders: Jeff Greason, Dan DeLong, Doug Jones, Aleta Jackson (1999)) [22 Space Settlement Institute, 2020]; Rocket Lab, American private space company that has its own rocket range in New Zealand. It has developed and successfully tested the ultra-light launch vehicle Electron (founders: Peter Beckd, location: Huntington Beach) (Incorporation, 2020).

In addition, fewer in number private space companies exist in other MTCR member States. For example, Russian space company Lin Industrial offers launches of medium orbit satellites up to $140 \mathrm{~kg}$ and up to $700 \mathrm{~kg}$ by their launch vehicles of small class [26 Lin Industrial, 2020]. In Japan, a private company Interstellar Technologies builds ultra-lightweight launch vehicles for launching nanosatellites into space. The founder of Taiki is Hokkaido, President of Akabira, Hokkaido, founded in 2005 (Mission, 2020). In Ukraine, a private space company Science and Space has declared itself (Founder: Valentyn Halunko (2020)), it is engaged in the development of light class launch vehicles for the launching of satellites with a total mass of up to $500 \mathrm{~kg}$ into a medium-orbit from sea launch (Science, 2020).

All of these companies have standard features: first, they are all overseen by national space agencies; second, they should comply with the MTCR guidelines; third, the export of manufactured products is carried out only after obtaining permission from the national export control services.

The legal system for ensuring the activity of private companies in non-MTCR States differs. For example, private Chinese space companies have made significant strides. Although, according to experts, they can be called private only provisionally. All of them, without exception, are supported by the State, and as the whole Chinese space is under the military umbrella. At the same time, there are nearly two dozen formally private rocket companies in China. The most successful of them is Expace, which is a subsidiary of the Chinese public company CASIC. It has successfully launched a four-stage solid rocket capable of delivering a payload of up to $700 \mathrm{~kg}$ into medium orbit (Overview, 2020).

The specificity of legal regulation of Chinese private companies is that the PRC does not have space laws, and national space provisions are established by two governmental resolutions, approved by numerous military orders. In addition, it should be emphasized that 
the PRC has not yet been accepted into the MTCR. Moreover, since this State has submitted an application to this regime, it generally respects its guidelines and requires this from its private space companies.

\section{Ballistic missiles proliferation beyond the MTCR is a critical threat to international security}

The United States and other nations make significant efforts to prevent the proliferation of missile weapons and take measures to prevent the States from having ballistic missiles. This is a complex task that restrains the transfer of finished missiles, rocket technology, financial and human capital needed to successfully develop mid-range launch vehicles and intercontinental missiles. North Korea is of particular concern to the world community due to numerous ballistic missile tests, and U.S. intelligence officials believe that North Korea has successfully developed an intercontinental missile capable of striking the continental United States. Unfortunately, the Missile Technology Control Regime has often been disrupted. In fact, the only coercive means to enforce the MTCR guidelines are sanctions that may be imposed by the United States (Knox, 2017).

For example, the first space-faring nation, Russia, which joined the MTCR in 1995, but before this, between 1987 and 1995, Russia transferred a number of ballistic missiles to other states. In particular, from Russia, Slovakia achieved ballistic missiles SS23, according to western classification. Belarus achieved ballistic missiles SS-1 and SS25, Armenia and Greece achieved ballistic missiles SS21, R-17 Elbrus and FROG-7. However, after joining the treaty, Russia, against the MTCR, transferred a ballistic missile SS26 to Armenia in 2016 (Knox, 2017).

Non-traditional is the legal status of China, one of the most powerful space powers in the MTCR. This is due to the fact that China has applied for membership and promised to adhere to its key guidelines. China advances its capacity to exercise national control over the export of missile technology. According to international reports, China is taking steps to train its space firms and government authorities on the guidelines for an export-related to rocket technology and the improvement of export controls related to rockets. For example, in January 2004, Beijing released an export licensing directory for items and technology to help customs officials identify weapons proliferation issues, and the Chinese Ministry of Commerce announced that it had fined two of its companies for violating export controls of MTCR's items. However, according to the CIA report, in 2004, despite these efforts, Chinese organizations continued to work with Pakistan and Iran on ballistic missile projects, and firms in China provided raw materials or dual-use items to other countries (Rasmussen, 2007). In addition, there is information that China sold a DF-21 ballistic missile to Saudi Arabia in 2007 (Knox, 2017).

Therefore, it should be noted that the Chinese government faces some difficulties in restricting the unauthorized transfer of controlled items and missile technology. According to Niels Aadal Rasmussen, it is inappropriate to further deny China's accession to the MTCR. The ways to bring its missile technology export control policy and infrastructure to an acceptable level of the MTCR (Rasmussen, 2007).

However, the bigger problem is the existence of space-faring nations that do not seek to enter into the Missile Technology Control Regime and do not adhere to its guidelines. North Korea and Iran are among the most technologically successful and dangerous for the world community in terms of the use of weapons of mass destruction. This is of great concern to the 
world community. In addition, almost all countries in the Middle East have ballistic missiles subject to the MTCR. These include Yemen, Saudi Arabia, Egypt, Israel, Iraq, Afghanistan, Turkey, Turkmenistan, Kazakhstan, the United Arab Emirates, Bahrain, and Pakistan. Among these States, only Turkey joined the MTCR (1997). Other countries in the Middle East, formally not part of the MTCR, can transfer ballistic missiles to each other. For example, in 2007, Iran transferred a ballistic missile to Syria (Knox, 2017).

Therefore, space powers outside the Missile Technology Control Regime undermine the effectiveness of missile proliferation and imposes unjust restrictions on Member States. After all, countries that do not seek to become MTCR partners can transmit missile technology to each other. Accordingly, first, intercontinental ballistic missiles are in state regimes (such as North Korea) where human life is of no value and the potential to blackmail democratic States exist; second, it discriminates the space industry in the MTCR Member States, which makes it difficult to attract investment in missile technology to non-members of the MTCR.

\section{Why and how to become a member of the missile technology control regime?}

The rationale for participation in the MTCR is: 1) the State either does not have at all or has not yet developed space industry, but wants to create one; 2) entrepreneurs of the State are eager to access dual-use high-tech; 3) the State wants to acquire a political image of spacefaring nation; 4) in cases where States without accession to the MTCR are already engaged in space development then the reason for accession is the desire to avoid political pressure and corresponding international sanctions (Ozga,1994).

Usually, the decision to adopt a new MTCR partner is taken by consensus. When deciding on membership, Member States shall first consider whether the applicant country persistently strives for the non-proliferation of ballistic missiles to establish an effective export control system that implements the MTCR Guidelines and Procedures, to control and implement such controls effectively. Dialogue with potential partners is conducted through the MTCR chairman, a visit to the capital of the applicant country by a committee consisting of representatives of four MTCR partners and bilateral exchanges between delegations (MTCR. 2020).

However, Deborah A. Ozga, a scholar in this field, argues that the State should not only proclaim itself to be an adherent to the regime, but also strictly adhere to its guidelines. This does not necessarily imply that an adherent will be automatically recognized by civilized space nations. For this, recognition of adherent status by the U.S. government is particularly critical. What is usually legalized is a preliminary agreement between the U.S. government and the Candidate State (Ozga, 1994). For example, in 1994, a Memorandum of Understanding on the Transfer of Missile Equipment and Technology was signed between the Governments of Ukraine and the United States. In particular, the parties will not allow any transfer of missile equipment or technology, except for individually issued licenses or other written permission granted for transfer to the appropriate government agency. The Parties shall give the strict presumption of rejection of any application for the removal of any missile equipment or technology of Category I (Memorandum, 1994).

Exceptions to this may be only the rare cases that meet the following requirements. First, the transfer of such equipment is permitted by the Missile Technology Control Regime, that is, the missile system has the maximum potential capability to launch satellites up to $500 \mathrm{~kg}$, with a range less than $300 \mathrm{~km}$; second, governmental commitments will be confirmed that: 1) these 
items will be used for peaceful and declared purposes; 2) such use will not be violated, and the items will not be modified or copied without the prior consent of the parties; 3 ) neither the items, nor their copies, or the related equipment will be re-exported without the permission of the supplier. In addition, the State of Ukraine assumes responsibility for all necessary steps, including on-site inspections in relevant cases, to ensure that the subject of the transfer is used for the stated purposes only (Memorandum, 1994). Subsequently, Ukraine implemented national export controls at the national level, provided for by the guidelines of the regime, as well as lists of corresponding goods, but actually acquired membership of the organization only in 1998.

However, according to Niels Aadal Rasmussen, MTCR membership may bring less advantage than expected. As the previous experience of other space powers such as Brazil and Ukraine illustrate, membership of the MTCR does not guarantee equal treatment by the U.S. and the E.U. in civilian space programs or technology sharing (Rasmussen, 2007).

Therefore, the Memorandum of the International Legal Control Regime for Missile Technology for Ukraine is more rigid than the very MTCR. After such strenuous commitments to the U.S. Government and in agreement with the other Member States, only four years later, Ukraine passed all the procedures foreseen and in 1998 became a full member of this esteemed society.

\section{Sanctions for violating the missile technology control regime}

No MTCR Member State can veto foreign exports of missile equipment and technology. However, U.S. law provides for the possibility of imposing national sanctions against violators (Stefanovich, 2020). Unfortunately, most other Member States do not impose sanctions for MTCR violations. They are usually limited to diplomatic actions.

According to U.S. national law, the President has the right to impose economic sanctions on national entities, and political and economic sanctions on foreign entities. For example, if they export or otherwise transfer MTCR equipment or technology, facilitate the acquisition, design, development or production of missiles in a non-MTCR country. If an entity is an intermediary, or tries to participate in such export, transfer or work, or promotes such export, transfer or trade by any other entity. However, the President of the United States may refuse to impose sanctions on such an entity if he believes that the export of a good or service is important to U.S. national security and proves it reasonably to Congress (Foreign, 1992).

According to recent provisions, U.S. space companies have been able to export ballistic missiles to Turkey (1988), Thailand (1993), the United Kingdom (1994), Greece (1996), South Korea (1999), Bahrain (2000) and the United Arab Emirates (2011). In five of the seven cases, the first category launch vehicles ready to use were transferred. Specifically, such ballistic missiles were sold to the United Kingdom, Greece, South Korea, Bahrain and the United Arab Emirates. Moreover, the United Kingdom has received a sophisticated ballistic missile from the United States with astronomically inertial warhead guidance and individual guidance to the target. But there are two cases of the transfer of individual components of the second category missile systems to Thailand and South Korea (Stefanovich, 2020). However, the U.S. government has repeatedly applied sanctions to foreigners. For example, in 2000 on subjects of Iran and North Korea engaged in activities to proliferate missile technology prohibited by MTCR (Missile, 2020).

Moreover, the United Kingdom has received the most advanced ballistic missile from the United States with astronomically inertial warhead guidance and individual guidance system. 
But there are two cases of the transfer of individual components of the second category missile systems to Thailand and South Korea (Stefanovich, 2020). However, the U.S. government has repeatedly applied sanctions to foreign entities. For example, in 2000 on it was the case of entities of Iran and North Korea engaged in activities to a proliferation of missile technology prohibited by the MTCR (Missile, 2020).

Therefore, the international legal mechanism for imposing sanctions on MTCR violators is not appropriate. Nowadays, virtually only the U.S. government imposes economic and political sanctions on foreign entities that violate it. Other MTCR Member States are limited to diplomatic measures only.

\section{Disadvantages of the missile technology control regime}

It is an axiom in law that any provision of law should be protected by a sanction. International provisions are no exception to this rule. Otherwise, a provision of law that is not protected by legal coercion will almost never be enforced. This is relevant to the Missile Technology Control Regime. Its non-adherence should be ensured by international sanctions, not national sanctions of individual States.

The problem of non-proliferation of missile technology is a very complex set of political, economic, legal, and technological issues that are unlikely to be resolved quickly and relatively painlessly (Novikov, 2012). Accordingly, the scientific literature highlights MTCR shortcomings such as: 1) a limited number of members; 2) by its legal nature, the MTCR does not have the legal status of an international treaty; it is not formally binding; 3) some of its guidelines are imperfect, not specific and interpreted differently by different States; 4) frequently MTCR membership provides the Member State not with a positive incentive to develop, but refusal to develop missile programs; 5) the regime does not offer the majority of Member States any advantages; 6) there are no international sanctions for their violation; 7) MTCR does not address all aspects of ballistic missile proliferation by totalitarian regimes that ignore international rules (Ozga,1994).

Therefore, countries that carefully adhere to the MTCR lose their space technology, for example, Ukraine. On the contrary, rogue States that violate international law make significant progress in launching ballistic missiles, for example, North Korea. Moreover, U.S. sanctions cannot stop further enhancement of North Korea's space and nuclear program.

\section{Improvement areas of the missile technology control regime, considering private space companies development}

The above study enables one to argue that classical international legislation on the peaceful proliferation of ballistic missiles is virtually absent. Therefore, States adhering to it are in worse condition than those that do not recognize or (and) violate it. Under the U.N., it must be built, approved, and, most importantly, set effective sanctions for violations. That is a very difficult task. The common security system in the form of the U.N. Security Council is not perfect or effective. However, further establishment of international legislation on the peaceful use of launch vehicles is required. Evidently, modern humanity increasingly become not Earth but cosmic one. It is impossible to stop this process.

It is important to emphasize that, prior to the adoption of high-level international legislation on the peaceful design, development, production, operation, export and launch of launch vehicles with civilian satellites and stations, all States, whether or not they are MTCR 
members, must strictly adhere to their guidelines. In relation to States that violate this regime, all Member States should be consolidated to impose strict political and economic sanctions. There is no other way.

In addition, we argue that, first, the procedure for joining MTCR by democracies governed by the rule of law should be simplified. Because the more civilized space powers are in society, the higher the development of overall social progress of the world economy through the use of space resources. Second, the procedure for democracies governed by the rule of law, applicants to the MTCR to use ready-made launch vehicles to launch their civilian satellites, should be simplified. Export should be with the exclusive right of use, without the right of ownership and regulations. It should be without the transfer of technical documentation and technology. Moreover, MTCR manufacturers' staff should provide maintenance of such missile systems. This will enable us to engage both public and private investments by individuals and legal entities of States currently uninvolved in the exploration and use of outer space. This will increase the MTCR status as an international institution. Furthermore, it will be a factor in counteracting the proliferation of ballistic launch vehicles in the uncontrolled civilized world community.

\section{Conclusion}

Therefore, the MTCR has long played a positive role in preventing the transfer of ballistic missiles and related technologies to terrorist organizations and totalitarian State regimes. However, it is not effective under the current MTCR. On the one hand, it does not deter States from successfully developing ballistic missiles and weapons of mass destruction. On the other hand, it hinders the development of space technologies by non-space club States. This is despite the fact that, under the present conditions, liquid and solid civilian engines are the only vehicles that provide access to Earth orbit and the long space of cargo and humans.

It is proved that humanity is in such a state that only civilian ballistic missiles make the Earth Man into the Cosmic Man. In other words, the proliferation of rocket technology among private companies of democracies governed by the rule of law not only increases the quality of life and work of people on Earth, but also increases the probability of human survival in the face of global natural and man-made disasters. Our further research will focus on the development of the theory and practical recommendations on a high-level international legal mechanism (at the U.N. level) to prevent ballistic missiles from entering terrorists. Nevertheless, simultaneously private companies, residents in democracies governed by the rule of law, should be provided with the conditions to build many new launch vehicles.

\section{References}

A/RES/68/262 (2014) Territorial integrity of Ukraine. Resolution adopted by the General Assembly on March 27 2014. United Nations. https://undocs.org/A/RES/68/262

Chechelyuk, Leonid (2013) Missile Technology Control Mode. State Export Control Service of Ukraine. http://www.dsecu.gov.ua/img/publishing/?id=47197

Foreign Relations and Intercourse (1992) U.S. Code Title 22. https://www.law.cornell.edu/ uscode/text/22

Frequently Asked Questions (FAQS) (2020) MTCR. https://mtcr.info/frequently-askedquestions-faqs/

Guidelines for Sensitive Missile-Relevant Transfers (2002) MTCR. https://mtcr.info/ guidelines-for-sensitive-missile-relevant-transfers/ 
Hofford, Casey (2019) Top 3 Biggest Private Space Companies. earth.com. https://www.earth. com/earthpedia-articles/top-3-biggest-private-space-companies/

Incorporation of Rocket Lab (2020) https://www.rocketlabusa.com/about-us/

Kasatkina, Svetlana (2011) Man and Space in the Philosophical and Pedagogical Views of K. Tsiolkovsky. Bulletin of Kostroma State University. Series: Pedagogy. Psychology. Sociokinetics. $\quad$ https://cyberleninka.ru/article/n/chelovek-i-kosmos-v-filosofskopedagogicheskih-vozzreniyah-k-e-tsiolkovskogo

Knox, Tyler J. (2017) The State of the Missile Technology Control Regime. University of Pennsylvania Scholarly Commons. https://repository.upenn.edu/cgi/viewcontent. cgi? article $=1022 \&$ context $=$ spur

Memorandum of Understanding between the Government of Ukraine and the Government of the United States of America on the transfer of missile equipment and technology on May 13 (1994) Approved by the Resolution of the Cabinet of Ministers of Ukraine dated 05.09.1994. No. 613. https://zakon.rada.gov.ua/laws/show/840_072

Missile Technology Control Regime (MTCR) (2017) Annex Handbook. https://mtcr.info/ wordpress/wp-content/uploads/2017/10/MTCR-Handbook-2017-INDEXED-FINALDigital.pdf

Missile Technology Control Regime (MTCR) News (2020) The Federation of American Scientists (FAS). https://fas.org/nuke/control/mtcr/news/index.html

Mission a family sedan for the stars (2020) Interstellar Technologies. http://www.istellartech. com/mission_en

MTCR Partners (2020) Missile Technology Control Regime. MTCR. https://mtcr.info/partners/

Novikov, Vladimir (2012) Status and prospects of the missile technology control regime. Problems of National Strategy No 1 (10). https://riss.ru/images/pdf/journal/2012/1/06_. pdf

Nuclear Weapons and WMD Delivery Systems (2020) The National Counterproliferation Center. https://www.dni.gov/index.php/ncpc-features/1551

On Earth, the sixth mass extinction began (2012) LiveJournal. https://martinis09.livejournal. com/1057660.html

Overview of private Chinese space companies (2020) Alpha Centauri. 2020 https:// thealphacentauri.net/29269-obzor-kitayskih-chastnyh-kosmicheskih-kompaniy/

Ozga, DeborahA. (1994)AChronology of the Missile Technology Control. The Nonproliferation Review. https://www.nonproliferation.org/wp-content/uploads/npr/ozga12.pdf

Public Statement from the Plenary Meeting of the Missile Technology Control Regime (2019) MTCR. https://mtcr.info/public-statement-from-the-plenary-meeting-of-the-missiletechnology-control-regime-auckland-11-october-2019/

Private Space Companies (2020) The Space Settlement Institute. Space Settlement Institute. http://www.space-settlement-institute.org/private-space-companies.html

Projects (2020) Lin Industrial. https://spacelin.ru/osnovnye-proekty/

Rasmussen, Niels Aadal (2007) Chinese Missile Technology Control — Regime or No Regime? https://www.files.ethz.ch/isn/29608/nra_chinese_missile_technology_control.pdf

Science \& Space (2020) http://scinspace.com.ua/new.html

Sheetz, Michael (2020) Space companies raised a record $\$ 5.8$ billion in private investments last year. CNBC. https://www.cnbc.com/2020/01/14/space-companies-includingspacex-raised-5point8-billion-in-2019.html 
Stefanovich, Dmitry (2020) Pre-strategic export and missile technology control regime. Cent analysis of strategy and technology. http://cast.ru/products/articles/dostrategicheskiyeksport-i-rezhim-kontrolya-za-raketnoy-tekhnologiey.html

Wall, Mike (2018) Stephen Hawking Never Reached Space, But He Sought to Lift All of Humanity. SPACE. https://www.space.com/39981-stephen-hawking-spaceexploration-advocate.html 